\title{
The United Nations and Human Security
}

\author{
S. Neil MacFarlane
}

\begin{abstract}
This article discusses the role of the United Nations in the development of the concept of human security since the 1998 Lysøen Declaration. The UN's role in the evolution of understandings of human security in international society is examined, emphasizing conceptual development, the incubation of ideas, consensus building, legitimation and codification, and practice. It also considers the limitations on the organization in promoting human security, given its state-centric character and substantial contestation of the idea of sovereignty in international society. The analysis suggests that the organization has played a significant role in the effort to define, promote, legitimize and implement elements of human security, but faces serious constraints given its state-centric nature.
\end{abstract}

Keywords human security, UN, responsibility to protect, sovereignty

\section{Introduction}

This article discusses the role of the United Nations in the evolution of the human security agenda in the 15 years since the Lysøen Declaration, issued in May 1998. The subject remains topical, not least in view of the UN's difficulty in addressing key challenges to human security. These include whether the international organization should, or can, mandate international action to halt the killing of civilians and other crimes against humanity, such as the use of chemical weapons in Syria.

The analysis suggests that the organization has played an important role in conceiving human security and advocating normative change around the concept. It has also provided a universal forum for its elaboration and a means for its partial legitimation. The organization has also facilitated the embedding of elements of the human security agenda in law, institutions, and practice. In this respect, the analysis speaks to a number of important themes in the literature on normative change. However, the state-centric quality of the UN, the process of decision making in the Security Council, and remaining commitments to norms 
of sovereignty and non-intervention among member states have hampered efforts to embed human security at the UN and in international relations more broadly.

Furthermore, I argue that the UN and its agencies should be seen as one set of actors in a complex constellation of individual leaders, governments, nongovernmental organizations, and regional and global multilateral institutions engaged to varying degrees and at various times in promotion of aspects of the agenda. The focus here on the UN should not be taken as under-appreciation of the importance of these other sets of actors. The UN is probably not the most significant actor in this process-but its role has been a necessary one.

In laying out this argument, I begin with a brief discussion of problems of definition. I follow with a discussion of the UN's role in furthering human security. Then I address a number of shortcomings of the UN that have had an effect on establishing the concept of human security and the human security agenda in international relations.

\section{Definitions}

The first question arising is what we mean by the United Nations. Referring to the $\mathrm{UN}$ as an actor in world politics is a shortcut that masks a complex institutional reality. The UN is a rather loose collection of more or less independent organizations with a wide array of responsibilities. Some, such as the General Assembly and the Security Council, are intergovernmental and deliberative. These two UN organs have quite different legal personalities and powers. The Assembly, comprising representatives of all member states, provides a forum for debate and, sometimes, consensus building. Its decisions are not binding, although some would say they provide a basis for soft law. Its remit is very broad. The Council comprises 15 members, five of whom are permanent and possess the power to veto resolutions before the body. Its remit is generally limited to international peace and security. Its decisions under Chapter VII of the Charter are legally binding. The Council has the authority to mandate the use of force by the UN, and to approve actions by regional organizations, or by states and coalitions of states, to address threats to peace and security.

These two UN organs are joined by numerous agencies that have operational responsibility in specific policy areas (e.g., UNICEF for children, UNESCO for culture and education, UNDP for development), staffed by professional civil servants, and, in theory anyway, reporting into the UN Secretariat headed by the Secretary-General. ${ }^{1}$ They identify and analyze issues within their functional areas, propose and advocate international legislation, develop programmatic solutions and implement those solutions. Some have international legal status (e.g. UNHCR), but many do not. These agencies may be subordinate to the UN Secretariat, or they may be largely independent of it (the IMF, World Bank, and 
UNHCR). Some rely heavily on state contributions through the UN budget process (UNDP). Others (UNICEF and, to an extent, UNHCR) have developed substantial autonomous funding streams through the solicitation of private donations or through direct donations from states. Many of these institutions and their heads have significant agency in their own right.

In short, when speaking of the "UN role" in human security issues one needs to take account of the multiple, and sometimes contradictory, dimensions of the UN system.

Defining human security is also challenging. First, the concept is open ended. Security is about the management, mitigation, or removal of threats to the core values of a referent institution, group, or individual. If the referent is "human beings," then the agenda could cover anything and everything that might threaten human survival, fulfilment or identity and dignity. ${ }^{2}$ An incomplete list might include: disease; water and water quality; access to land, jobs, and education; human rights violations; criminality, war, and terrorism; migration (voluntary or forced, legal or illegal); the impact of globalization on cultural values; inequality and the absence of economic opportunity; resource depletion and climate change. In that context, there has been a fair amount of criticism of the allegedly boundless breadth of the agenda (see Owen et al. 2004).

Second, there is ambiguity regarding the referent object. Is human security about human beings as individuals or about human beings as members of collectivities (village, ethnicity, nation, religion, gender, the human species), or both? It is hard to demarcate the two; for example, since identity is generally defined in reference to a group, it is not clear how one would secure individual identity without securing group identity. Likewise, if the individual's economic welfare derives from participation in group economic activities, then securing individual welfare depends on securing the welfare of the group. On the other hand, the history of nationalism, for example, is replete with examples of nations attempting to secure themselves at the expense of the security of dissenting individuals within them.

Third, within the "human security agenda" different people and different institutions place their emphasis on different issues. One aspect of this phenomenon is a debate on narrow versus broad approaches to human security, much of which has played out within UN institutions (see Zaum, Ocampo and Eyben 2013, 124-125; compare ICISS 2001 and Commission on Human Security 2003). One key element of contestation here is the focus on protection from violence versus that on empowerment through development. A second is the distribution of responsibility between states and international institutions in the implementation of human security. ${ }^{3}$

These disputes reflect not only genuine differences of perspective and interpretation, but also the interests of institutions involved in a competition for scarce resources. Security is a value-laden concept. To call your issue a security 
issue enhances its salience in the policy arena; it is seen to be more "important."

It is not obvious how these questions could be resolved, since the concept of security and its human security variant are socially constructed and essentially contested (Gallie 1956, 167-198). For the purposes of the analysis that follows, I take human security fundamentally to be about recognizing human beings, as individuals, to be the principal bearers of rights and, therefore, the central focus of security. In this view, states are derivative bearers of rights. States have no irreducible claim to security. State security matters insofar as states foster and maintain environments in which human beings are physically secure, can prosper, and can live in dignity. In other words, the central analytical move is to contest traditional conceptions of security that privilege the state as the principal referent and to propose that human beings are the ultimate focus of security.

If there is a shift from states to individuals in conceptualizing and practicing security in international relations, this is a major change. It is a substantial departure from the normativity and practice of the Westphalian states system, which was about states (or sovereigns) and their mutual relations. In that system, human rights were considered to be matters essentially of domestic jurisdiction. Human security is rooted in a long string of normative and legal developments over the past 120 years, and notably, the United Nations Declaration on Human Rights and the later Covenants on Civil and Political Rights and Economic, Social and Cultural Rights. In this sense, this reframing of security is part of a much larger and sustained movement in international society to make the rights of individual human beings and their communities matters of legitimate concern in international relations.

\section{The UN and Human Security}

The focus on the security of human beings, individually or in groups, poses an immediate problem for the UN. The Charter highlights the essentially interstate quality of the organization: Articles 3 and 4 limit membership to states. The Charter's original conception of security is also state-centric. It prohibits the aggressive use of force by members and focuses on the control of conflict between members (Article 2, and Chapters 6 and 7). Recognizing the equal sovereignty of members, the Charter also limits the authority of the UN to involve itself in the internal affairs of member states (Article 2.7). Given the statist emphasis of the Charter's treatment of security, one might say that the organization is genetically handicapped in its pursuit of human security.

Nonetheless, and perhaps surprisingly, the organization has played a significant role both in redirecting security towards the human referent and in embedding human security in international norms and practice. The international community and its constituent parts are making slow and uneven 
progress towards embracing and implementing a human security agenda. The UN has made important contributions to the conceptualization, promotion, institutionalization, legitimation, and implementation of human security.

\section{Conceptualization and Advocacy of Human Security}

United Nations agencies played a key role in the gestation of the idea of human security. Although the tensions between the state and human levels of security had long been evident in discussions of security (MacFarlane and Khong 2006, 19-138), the term "human security," and the underlying multilateral effort to reorient analysis and practice of security towards human beings, originated in the UN-in the work of Mahbub ul Haq and the UNDP Human Development Reports to which he contributed in the early 1990s (UNDP 1994). The 1994 report initiated the debate on broad versus narrow, and developmental versus protective, versions of the concept. It put forward the initial statement of the position that human security was fundamentally about human development and empowerment, and proposed that the post-Cold War peace dividend be directed towards these ends. Although the project to institutionalize this understanding at the Copenhagen Social Summit in 1995 was stillborn, this early work had substantial influence on the report of the Commission on Human Security, which is discussed in more detail below.

Secretary-General Kofi Annan played a considerable role in generating interest in what came to be known as the Responsibility to Protect (R2P). In 1999 he noted the sovereignty concerns of member states and their consequent discomfort with notions of multilateral intervention on humanitarian grounds, as well as the problem of securing multilateral authorization for intrusion into domestic jurisdiction. He then asked a simple question in respect to Rwanda and Kosovo:

To those for whom the greatest threat to the future of international order is the use of force in the absence of a Security Council mandate, one might ask-not in the context of Kosovo-but in the context of Rwanda: If in those dark days and hours leading up to the genocide, a coalition of states had been prepared to act in defence of the Tutsi population, but did not receive prompt Council authorization, should such a coalition have stood aside and let the horror unfold? (UN 1999)

One result of the ensuing debate was the initiation of the International Commission on Intervention and State Sovereignty (ICISS 2001), whose report focused heavily on the protection of civilians from violence, and the role of international institutions therein, as key elements of the human security agenda.

Kofi Annan was also instrumental in initiating the work of the Commission on Human Security, which greatly developed Mahbub ul Haq's exploration of the socio-economic dimensions of human security. The report was an ambitious 
attempt at comprehensiveness in thinking about human security, embracing both protection and people-centered development and empowerment (Commission on Human Security 2003).

On other issues related to protection, UN High Commissioner for Refugees Sadako Ogata played a key role in highlighting the security vulnerability of refugees and displaced persons, not least at the meeting in Lysøen in 1998. Relatedly, in 1992 Secretary-General Boutros Boutros-Ghali appointed a Representative of the Secretary-General on internally displaced persons (IDPs), Francis Deng. Over the next three years, Deng studied the strengths and weaknesses of, and gaps in, existing standards relevant to protection of IDPs. This compilation served as the basis for a UNHCR staff field manual for addressing IDP issues. On the basis of this work, Deng was encouraged by the General Assembly and the UN Human Rights Commission to develop a set of guidelines concerning international treatment of IDPs. The guidelines were presented to the Human Rights Commission and the Economic and Social Council in 1998 (Commission on Human Rights 1998). They have since been embraced by a growing number of member states of the UN. The story is a good example of the expertise and advocacy of a UN official, encouraged by UN structures, producing a shift in the normative frame on an issue central to the protection component of the human security agenda.

These examples suggest that the UN has played a significant agency role in generating the concept and agenda of human security and in framing the debate around it. Prominent UN officials in the Secretariat and the specialized agencies have also played an important advocacy role in enhancing the profile of central human security challenges.

\section{Legitimation and Codification}

There are also many examples of the UN's role in the legitimation, codification, and institutionalization of human security. One is the Security Council process of deliberation concerning the international protection of civilians in conflict. As noted earlier, international enforcement actions to protect civilians at risk from conflict are in tension with conventional understandings of sovereignty and domestic jurisdiction. Early Security Council authorizations of action within the domestic jurisdiction of states (e.g., Somalia, Bosnia Herzegovina, and, belatedly, Rwanda) had been ad hoc. Often the enabling resolutions stressed that action in a particular case should not be considered as a precedent building towards a general rule (MacFarlane and Khong 2006, 164-201). However, in 1999 the President of the Security Council issued a statement drawing attention to the protection of civilians as a general problem and requesting that the Secretary-General make recommendations on how the Council should address it (President of Security Council 1999). The Secretary-General's report generalized the principle that systematic violations of human rights or international humanitarian law could 
constitute threats to international peace and security. It recommended that the Council consider enforcement action in the context of intense violations, the state's inability to protect or its complicity in infringements, and when peaceful consent-based efforts had been exhausted.

The Council responded with two resolutions expressing its agreement with this potential extension of threats to international peace and security to include humanitarian matters. It accepted that, in certain conditions, it would use its enforcement powers to protect civilians affected by violence, or humanitarian workers denied access to people in need (UN Security Council 1999; 2000). The lack of distinction between civil and interstate disputes in the resolutions suggested that sovereign rights of states were to a degree conditional upon a state's capacity and will to protect its own population from violence.

This theme was taken up in the 2005 General Assembly Summit Outcome. The document somewhat ambivalently embraced the responsibility to protect civilians in conflict. It accepted that, where states could not or would not fulfill this responsibility themselves, the United Nations reserved the right to take collective action through the Security Council (UN General Assembly 2005, pars. 138, 139). Despite its ambivalence, the Summit Outcome was an important milestone. The member states of the United Nations collectively embraced the proposition that there are circumstances when sovereignty can be overridden by a multilateral organization in defence of human beings and their rights within a state.

Looking further at the Lysøen agenda ${ }^{4}$ reveals a number of other milestones. One is the Ottawa Treaty on land mines. The UN played an active advocacy role, including statements by the Secretary-General, and the promotional and coordinating activities of the UN Department of Humanitarian Assistance (UNDHA), the UN Children's Fund (UNICEF), and the UN High Commissioner for Refugees (UNHCR) (Hubert 2000).

The land mines example exposes another facet of the UN's human security role. The central roles in the process leading to the treaty clearly belonged to the International Committee to Ban Land Mines, the International Committee of the Red Cross, and a small number of state advocates, notably Canada and Norway. However, the UN agencies' embrace of the land mines agenda played a significant role in legitimizing and furthering the process of banning them. One could also mention such initiatives as the "Optional Protocol to the International Convention on the Rights of the Child on the Involvement of Children in Armed Conflict" concerning child soldiers (UN 2004, 236-241). The conclusion would be similar.

Another aspect of the Lysøen agenda was the establishment of individual criminality and international means of adjudication of such criminality. The idea of an international court to address crimes of war and crimes against humanity arose after World War I in the League of Nations and gestated in the UN General 
Assembly and in the UN's International Law Commission after the Nuremberg Trials. The pace accelerated after the Cold War, not least because of events in the former Yugoslavia and in Rwanda. In both these cases the Security Council mandated the creation of courts to adjudicate crimes of genocide and other violations of international humanitarian law specific to the situation in question.

The proposal to establish a court of universal jurisdiction came out of the work of the International Law Commission in 1994, around the time the two particular courts just mentioned were established. The General Assembly then agreed to establish a preparatory committee for the establishment of an international court. In spite of opposition from a number of major states who were reluctant to see their military personnel and other state officials subject to the jurisdiction of an international judicial body, the process culminated in the Rome Statute of the International Criminal Court (ICC), adopted on July 17, 1998, and entering into force on July 1, 2002. The Rome Statute provided for the establishment of the Court and defined its remit. Although the ICC sits outside the UN system, the role of the UN in its establishment is clear. Concerning the UN's role, the process of negotiation leading to Rome grew out of earlier consideration of the problem in UN organs. Moreover, the Statute makes provision for the Security Council to refer cases to the ICC. ${ }^{5}$

The Rome Statute codifies formal definitions of genocide, crimes of war, and crimes against humanity. It establishes an independent international organization whose role in law is to investigate, prosecute, and adjudicate crimes of this sort by individuals. Potential offenders include officials acting under the authority of the state in the state's own domestic jurisdiction. The ICC process amounts to a substantial increase in multilateral oversight of state performance where the survival and basic rights of human beings are concerned. However, in a manner similar to the Summit Outcome's embrace of the international Responsibility to Protect, the primary responsibility for pursuing cases against individuals rests with the state in question. The ICC is a last resort. It cannot act if the state of jurisdiction is conducting a "genuine" investigation and prosecution of an accused individual. It is to be used in cases where a state is unable or unwilling to prosecute through its own judicial processes, or where the process is not impartial.

Taking the Responsibility to Protect, land mines, children in war, and the ICC together helps us to understand the role of the UN in promoting human security. In some cases UN agencies promoted change directly in throwing down challenges for others to pick up. Also, major figures within the UN (the Secretaries-General and leaders of UN agencies, such as Sadako Ogata, Francis Deng, and James Grant) exercised personal agency. The UN served as a forum for advocacy and consensus building. UN agencies were often partners in multilevel (NGOs, states, and international organizations) coalitions to further the agenda. 


\section{Implementation}

Taking the distinction between narrow and broad conceptualizations of security as a point of departure, this section discusses the trickling down of R2P principles into peacekeeping policy and practice, and the pursuit of the human development agenda through the Human Security Trust Fund.

Concerning the first issue, during fieldwork in Georgia in the late 1990s I interviewed a UN military observer in the security zone between Abkhazcontrolled and government-controlled territory. There had been a number of serious human rights violations in the zone in which he operated. I asked him about this. He complained about the demands from local residents for protection and assistance. He said that if he and his colleagues responded to such things the observer force could not do what it was supposed to do-observe Russian and local forces in and around the zone of control and monitor heavy weapons storage. It was a good encapsulation of the traditional place of civilian protection in peacekeeping mandates.

It is unlikely one would hear a senior peacekeeping officer say something like that today. That change is in part a result of UN efforts to embed civilian protection in Security Council deliberations and to translate it into the mandates and training of peacekeepers. Since the first inclusion of protection of civilians from violence in a force mandate (UNAMSIL in Sierra Leone in 1999-2000), the function has become standard for mandates in war or post-war situations. Mandates have widened considerably beyond protection to include a raft of other issues related to human security. These include gender, human rights, children in conflict, de-mining, and the disarmament, demobilization and reintegration of combatants (DPKO 2013). The widening of mission mandates has expanded the circle of agencies involved. The staffing of peacekeeping missions has broadened considerably, with civilian contingents addressing gender, human rights, children in conflict, etc. In short, the human security agenda now permeates the responsibilities of peacekeeping missions, the staffing of missions, and the programs they implement in the field.

Turning to the developmental aspect of the broader human security agenda, as already noted, the UNDP initiated reconceptualization of human development as human security. Their effort to embed this notion in UN institutions was revived in the 2003 report of the Human Security Commission. One consequence of the report was the creation, in 2004, of the Human Security Unit (HSU) in the Office for the Coordination of Humanitarian Assistance (OCHA) and the transfer of administration of the Trust Fund for Human Security (largely funded by Japan) to this new unit. The HSU has a broad remit to promote the Commission's vision of human security: protection and empowerment to achieve freedom from fear, freedom from want, and freedom to live in dignity. Consistent with the seeming bifurcation in the UN's development of the concept of human security, 
the protection aspect of HSU activities focuses on prevention and peacebuilding, but is silent on the question of intervention/enforcement, and is careful to avoid any interrogation of sovereignty (UNOCHA 2013).

The HSU promotes the idea of human security in the General Assembly, responds to situations of human insecurity through project work, develops practical tools for the application of the human security framework in the field, and disseminates lessons learned from human security activities (see UNTFHS 2013). It also develops training tools for UN agencies and sponsors regional workshops to mainstream human security in the UN system (Human Security Unit 2009).

In short, there is ample evidence within the UN system of trickle-down from conceptualization, legitimation, and codification to implementation (practice). This involves mandates and staffing of peace operations, revision of training practices for peace operations and for human development, and the funding of projects informed by the human security agenda.

\section{Limitations on the UN's Role in Human Security}

In these respects, the United Nations has played a substantial role in furthering human security. However, the record since the 1990s also displays significant shortcomings that limit the effectiveness of the UN in the promotion of the human security agenda. A quick glance at the protection agenda is illustrative. One key issue is disagreement among the members concerning enforcement action to protect civilians in conflict. Many member states of the General Assembly and the Security Council are very protective of what they deem to be their sovereign rights.

Where the interests or perspectives of the Security Council's five permanent members are competitively engaged, and when UN security decision-making depends on the agreement of the Permanent Five (P5) to put their particular preoccupations aside in favour of effective collective action, the UN often finds it impossible to act to protect human security. ${ }^{6}$ The war in Chechnya (1994-1996, 1999-2005), in which the Russian Federation brutalized the Chechen people, provides one example. In the Security Council, there has been no discussion of, let alone action with respect to, this conflict. Another was the failure of the Council to react meaningfully to the deteriorating situation in Kosovo in 1999. In the current context, the failure of the UN to take meaningful enforcement action to stop the mass killing of civilians in Syria does not foster optimism about the capacity of international law and institutions to protect some people caught up in conflict.

In short, the UN's mandating of enforcement to protect civilians is sporadic and selective, depending as it does on how the P5 perceive their particular 
interests in the situation at hand. This is particularly evident when the victims that need protection are within the domestic jurisdiction of a P5 state (as with Chechnya in Russia and Xinjiang in China), or when a perpetrator is closely allied with a P5 member (arguably the case with Syria). This is not merely a matter of conflicting interest. At least two of the P5 members (China and Russia) are hostile to the redefinition of sovereign rights inherent in the Responsibility to Protect, because it conflicts with their understanding of states' rights and international law. Several additional problems arise. One is the creation of a double standard. The UN acts to enforce when the P5 are willing to mandate it; it does not act when the P5 are not willing, or when acting collectively is inconsistent with particular interests of a member or members of the "club." This inconsistency impedes wider acceptance of the Responsibility to Protect. As Kofi Annan put it: "If the new commitment (sic) to intervention in the face of extreme suffering is to retain the support of the world's peoples, it must be-and must be seen to befairly and consistently applied, irrespective of region or nation" (UN 1999).

The inconstancy of Security Council response also encourages action outside the legal framework of Security Council authorization, as in Kosovo in 1999. Concerning consideration of enforcement action in Syria, one author noted that President Obama took the view that "taking limited military action in Syria was the right choice even without the support of the UN Security Council, which he [Obama] said was 'completely paralysed and unwilling to hold Assad accountable"' (Lewis 2013, 2). Precedents thus created may weaken the fabric of international law concerning the use of force. Finally, the legitimation (through appeal to $\mathrm{R} 2 \mathrm{P}$ or other human rights principles) of the practice of intervention may be used to justify aggression, as occurred in Iraq in 2003, Georgia in 2008, and Ukraine in 2014.

It is hard to see how the Council, as currently constituted, could reliably enforce the Responsibility to Protect; there is no reason to believe that the P5 would, as a group, sacrifice their particular interests in order to pursue universal protection. On the other hand, it is hard to see how the Council could be reformed in order to be able to do so. It is improbable that the P5 would surrender their veto privilege. It is not obvious that any alternative construction of the Security Council would be better from the perspective of the protection of human beings.

Turning to the General Assembly, the tension mentioned above between the rights and protection agenda on the one hand, and the conservative conception of sovereignty and the principle of non-intervention on the other, is evident in the 2005 Summit Outcome Document. Proponents of the Responsibility to Protect cite the document as evidence of endorsement of the principle by the international community. And so it is.

But the devil lies in the details. In the brief section of the document addressing protection, Paragraph 138 restates the primacy of the state in 
addressing human protection issues within its territory. Paragraph 139 states that the UN may consider action through the Security Council under Chapters VI and VII of the Charter on a case-by-case basis when national governments fail to protect their populations from genocide, crimes of war, and crimes against humanity (UN General Assembly 2005). Given widely different perspectives in the General Assembly and the Security Council on the derogation of sovereignty on human rights grounds, one can easily see how defining the threshold between 138 and 139 would be a highly contentious political issue. The fundamental problem is that, at both the Security Council and the General Assembly, the Responsibility to Protect cuts across the perceptions and policies of many member states. There is no consensus on how to implement this principle. It is unavoidable, therefore, that it should be incompletely and unevenly applied.

In practice, where the UN does apply the principle the enhancement of human security is sometimes hard to find on the ground. One example would be a recent Save the Children report that established that the worst place in the world to be an expectant mother was the Democratic Republic of Congo (DRC) (Save the Children 2013, 9). The DRC hosts a UN security presence (MONUSCO) with 23,407 personnel, the second largest current peacekeeping operation. There have also been a number of cases in which, far from protecting civilians, some peacekeepers have themselves been a hazard to the security of human beings, for example, in the form of sexual abuse of women and girls (see Defeis 2008).

Concerning codification of aspects of the human security agenda, it bears mentioning that many of the key treaties and conventions have not been universally accepted. The Rome Statute aims to end impunity with regard to crimes of war and crimes against humanity. However, many states, such as China, have not signed the treaty and do not accept the ICC's jurisdiction. Others, such as Russia, have signed but have not ratified the treaty and hence are not members. Still others (Israel, Sudan, the United States) signed the treaty, but have indicated subsequently that they have no intention to proceed to ratification.

Despite the ambitions of the ICC, and its impressive organization, its effects in ending impunity have been modest. Since its establishment in 2002, eight situations have been brought to the Court. The Security Council referred two of the eight situations (Darfur and Libya), four were self-referrals, and two were brought to the attention of the Court by the prosecutor, acting proprio motu (on his own initiative). Investigations of these situations have produced 18 cases. The numbers are somewhat deceptive in terms of the large agenda of ending impunity, since such situations and cases are to be handled by the states of jurisdiction in the first instance. The ICC is a last resort. Even so, there are numerous situations (the most obvious being Syria) where neither national judicial procedures nor ICC procedures have been activated to deal with, or have been effective in dealing with, crimes against humanity.

All eight situations currently under active consideration by the ICC are in 
African countries. The Court is also considering taking up issues in Afghanistan, Colombia, Georgia, Guinea, and Honduras. This list of 13 contributes to the perception against which Kofi Annan warned: If the protection agenda is notand is not seen to be-impartial and universal, it will be perceived as a selective vehicle for the imposition of Western values on southern states and societies.

With regard to codification of other elements of the human security agenda, three out of five permanent members of the Security Council (China, Russia, and the United States) have not signed the Land Mines Treaty. The Optional Protocol on Child Soldiers has been accepted more widely, but the forced recruitment of children into combat units continues. UN and related efforts at demobilization and reintegration of child soldiers in ongoing conflicts, such as that in the DRC, frequently have disappointing results.

The broader definition of human security pursued by the HSU and the Trust Fund for Human Security encounters far less political and cultural resistance. The HSU claims a practical role in protection and empowerment of individuals and communities. It has funded a wide array of projects proposed by other UN agencies. ${ }^{8}$ Projects implemented follow closely the protection/empowerment logic. Major issues addressed include health and disease prevention, disaster preparedness, restoring or enhancing rural livelihoods, community development, post-conflict peacebuilding and reconciliation, human trafficking, and community violence. Vulnerable populations are a particular focus among beneficiaries: children and youth, women and girls, displaced or migrant populations, and populations affected by conflict. Review of allocation suggests a particular concentration of resources in societies in conflict or post-conflict situations. Current grant guidance suggests single organization projects should budget around one million U.S. dollars per project, and groups of organizations should aim at $\$ 2.5$ million. Historically, project grants have ranged between $\$ 100,000$ and $\$ 20$ million, but most have fallen between $\$ 1$ and $\$ 5$ million. Total funds allocated since the inception of grant activities come to roughly $\$ 230$ million. ${ }^{9}$

This is not a lot of money in contrast to the total size of national official development assistance (ODA) budgets, the total spent in conflict management and post-conflict programming, or the total annual ODA of all OECD members. However, the purpose of these programs is to act as pilots for the dissemination of the "human security approach" into aid programming more broadly. It is difficult to assess the extent to which this has been successful. However, there is no reason to doubt that the impact of these projects on beneficiaries is positive. On the other hand, the fact that the focus is on pilot projects in the hope that the approach will be emulated in programs mounted by other multilateral, national, and nongovernmental donors and organizations underscores the limits on the role of the UN per se in implementing a broad human security agenda, as well as the continuing reliance on major states to provide the bulk of resources. 
In other words, although much progress has been made in implementing elements of the human security and rights agenda, there remains considerable distance to go. Many aspects of the UN's agenda face resistance at many levels, not least that of key states or groups of states. The rhetoric is often far ahead of the practice. The ambition outstrips the resources available to pursue it.

\section{Conclusion}

The 15-year period since the Lysøen Declaration has witnessed substantial progress in embedding human security in international relations. In essence, the emergence of the concept of human security reflects a fundamental change in the way we understand international relations and international security. That change speaks to the rights of human beings in a system traditionally dominated by states. Human security emphasizes the rights of people to live free from fear and the duty of the international community to address this challenge when states cannot or will not do so. It makes states and their leaders and officials internationally accountable for their treatment of their own citizens, what Kathryn Sikkink referred to in a recent book as the "justice cascade" (Sikkink 2011). It also highlights the rights of individuals and communities to have control over their own lives and to live in dignity (i.e., empowerment).

The United Nations has played a significant role in conceptualizing human security, and in promoting it. It has also provided a forum for building a modicum of consensus around the humanization of security. Much of the work on legitimizing and, in some cases, codifying and institutionalizing this agenda has occurred within the United Nations system. The United Nations has been instrumental in embedding aspects of human security in both security and development practice.

That the United Nations sought to pursue this agenda is a product of individual agency and leadership within the organization. However, institutional engagement has often been the result of advocacy by member states and by international civil society. Successes in codification and legitimation have occurred in considerable measure because states have supported the process. States have engaged in the promotion of human security in part because of pressure from national and international civil society. To the extent that normative change has occurred, it has frequently been achieved as a result of the initiative of like-minded states and NGOs, partnerships among them, as well as partnerships between them and those units of the UN System sympathetic to these projects. Perhaps the most important role of the organization has been to provide a structure in which a revision of the discourse of appropriateness related to security can evolve in a human direction.

When we think about the causes of normative change we are often 
overwhelmed by the problem of over-determination and the conjuncture of multiple causes. It is very difficult to determine what the role of a particular institution or cluster of institutions might be in complex change. However, counterfactual analysis may help. Civil society, like-minded states, and particular individuals have acted as norm entrepreneurs. However modest the progress that has been made in embedding human security in the norms and practice of international society, nothing or little would have occurred without these sets of actors. On the other hand, it is hard to conceive of this modest flourishing of the human security agenda without the UN playing the roles described above. Not least, it has provided a near-universal forum in which these questions can be argued out, and in which agreed conclusions receive the legitimation associated with broad consensus.

In other words, both sides of the human security partnership have been necessary conditions for forward movement. But neither has been sufficient. The Syrian case suggests clearly that international society has not fully established the fundamental principles of human security. And human security practice is far from reliable when it comes to consistent enforcement and implementation, in considerable measure because of the resistance or indifference of states, including major state actors.

However, systemic normative change generally occurs slowly, with numerous hiccups and reversals. A shift from the state referent as the focus of security to the human referent was certain to encounter significant resistance from states unwilling to surrender their prerogatives. State resistance has been a significant brake on establishing human security. Given that the UN is, at the end of the day, an organization of states, it is no surprise that state resistance has circumscribed the UN role in human security. Indeed, given its origins and makeup, it is a surprise that it has contributed as much as it has.

\section{Notes}

1. Inis Claude referred in this context to the two UNs: the intergovernmental arena and a professional secretariat (Claude 1956; 1996). In the 2000s, some scholars proposed consideration of a "third" UN, comprising NGOs and networks of experts and advocates with close ties to UN organizations (Weiss, Carayannis, and Jolly 2009). This proposition is not directly addressed here, but is implicit in the discussion of interaction between the UN and other entities later in this paper.

2. This breadth is clear in the report of the Commission on Human Security (2003, 4), which described the essence of human security as the creation of "political, social, environmental, economic, military, and cultural systems that together give people the building blocks of survival, livelihood, and dignity."

3. The 2012 effort by the General Assembly to arrive at a consensus on defining human security is an interesting document in this regard, not least in its distinction between 
human security and the Responsibility to Protect, the focus on state sovereignty and nonintervention, empowerment through development, and the remark that "human security does not entail the threat or use of force or coercive measures" (UN General Assembly 2012).

4. The Chairman's Summary of the Lysøen Conference on Human Security (Lysøen Conference 1998) lists several elements of a practical human security agenda: antipersonnel landmines, small arms, children in armed conflict, international humanitarian and human rights law, the international criminal court, worker safety, conflict prevention, transnational crime, and resources for development.

5. States can also refer cases concerning individuals under their jurisdiction. Individuals and organizations other than states can provide information that may subsequently lead to prosecutorial investigation proprio motu (on his own initiative). For general background, see ICC 2013.

6. One Russian analyst, in explaining Russia's obstruction of international action in Syria, noted that "for Putin, Syria was above all about the principles of sovereignty and non-interference" (Trenin 2013).

7. This perception is one factor underlying the African Union's announcement that its members would not cooperate with the Court on the case against Sudan's President Omar Bashir. See also Paul Kagamés remark that the ICC "has been put in place only for African countries, only for poor countries," and Richard Goldstone's observation that the ICC "appeared too focused on crimes on the continent of Africa, while paying scant regard to similar situations elsewhere in the world," as quoted in Kimani 2009. For background, see Tladi $(2009,58)$ : "From a more normative perspective, the decision raises questions about the reality of a new value-based international law, centered on the protection of humanity and human rights and whether such a new international law can escape accusations of neoimperialism."

8. For the Trust Fund guidelines, see UNOCHA 2012.

9. This figure is derived from the budget envelopes of projects listed in UNTFHS 2013b.

\section{References}

Claude, Inis. 1956. Swords into Plowshares: The Problems and Progress of International Organization. New York: Random House.

Claude Inis. 1996. "Peace and Security: Prospective Roles for the Two United Nations." Global Governance 2: 289-298.

Commission on Human Rights. 1998. Guiding Principles on Internal Displacement. http://daccess-dds-ny.un.org/doc/UNDOC/GEN/G98/104/93/PDF/G9810493. pdf?OpenElement (accessed September 25, 2014).

Commission on Human Security. 2003. Human Security Now. New York: Commission on Human Security. http://www.unocha.org/humansecurity/human-security-now (accessed September 25, 2014).

Defeis, Elizabeth. 2008. "UN Peacekeepers and Sexual Abuse and Exploitation: An End to Impunity." Washington University Global Studies Law Review 7 (2): 185-214.

DPKO (Department of Peacekeeping Operations). 2013. Peace-keeping Issues. New York: United Nations. http://www.un.org/en/peacekeeping/issues/ (accessed September 25, 
2014).

Gallie, William. 1956. "Essentially Contested Concepts." Proceedings of the Aristotelian Society 56: 167-198.

Hubert, Don. 2000. The Land-Mine Ban: A Case Study in Humanitarian Advocacy, Occasional Paper 42. Providence RI: Watson Institute. http://www.watsoninstitute. org/pub/op42.pdf (accessed September 25, 2014).

Human Security Unit. 2009. Human Security in Theory and Practice: Application of the Human Security Concept and the United Nations Trust Fund for Human Security. New York: United Nations. https://docs.unocha.org/sites/dms/HSU/Publications\%20 and\%20Products/Human\%20Security\%20Tools/Human\%20Security\%20in\%20 Theory\%20and\%20Practice\%20English.pdf (accessed September 25, 2014).

ICC (International Criminal Court). 2013. "Situations and Cases." The Hague: ICC. http:// www.icc-cpi.int/enmenus/icc/situations\%20and\%20cases/Pages/situations\%20 and\%20cases.aspx (accessed September 25, 2014).

ICISS (International Commission on Intervention and State Sovereignty). 2001. The Responsibility to Protect. Ottawa: International Development Resource Centre.

Kimani, Mary. 2009. "Pursuit of Justice or Western Plot?" Africa Renewal Online. October. http://www.un.org/africarenewal/magazine/october-2009/pursuit-justice-or-westernplot (accessed September 25, 2014).

Lewis, Paul. 2013. "Obama Seeks Congress Vote before Military Strike on Syria." The Observer, September 1.

Lysøen Conference. 1998. Chairman's Summary. http://cpsindia/peacetheme.htm (accessed September 25, 2009).

MacFarlane, S. Neil, and Yuen Foong Khong. 2006. The UN and Human Security: A Critical History. Bloomington, IN: Indiana University Press.

Owen, Taylor, and Peter J. Burgess, eds. 2004. "Special Section: What Is 'Human Security'?" Security Dialogue 35 (3): 373-387.

President of the Security Council. 1999. "Statement by the President of the Security Council.” February 12. New York: United Nations. http://www.un.org/ga/search/ viewdoc.asp?symbol=S/PRST/1999/6 (accessed September 25, 2014).

Secretary-General of the United Nations. 1999. "Report of the Secretary-General to the Security Council on the Protection of Civilians in Armed Conflict." New York: United Nations. http://www.un.org/ga/search/viewdoc.asp?symbol=S/1999/957 (accessed September 25, 2014).

Save the Children. 2013. Surviving the First Day: State of the World's Mothers 2013. Westport, CT: Save the Children USA. http://www.savethechildren.org/atf/ cf/\%7B9def2ebe-10ae-432c-9bd0-df91d2eba74a\%7D/SOWM-FULL-REPORT_2013. PDF (accessed September 25, 2014).

Sikkink, Kathryn. 2011. The Justice Cascade: How Human Rights Prosecutions Are Changing World Politics. New York: W.W. Norton.

Tladi, Dire. 2009. "The African Union and the International Criminal Court: The Battle for the Soul of International Law." South African Yearbook of International Law 34: 57-69.

Trenin, Dimitry. 2013. "Russia's Middle East End Game, at the Hands of the Post-Soviet Grand Master." Tablet, August 1. http://carnegie.ru/2013/08/01/russia-s-middle-eastend-game-at-hands-of-post-soviet-grandmaster/gh3o (accessed September 25, 2014).

UN (United Nations). 1999. "Secretary-General Presents His Annual Report to the 
Assembly." Press Release. New York: United Nations. http://www.un.org/News/Press/ docs/1999/19990920.sgsm7136.ht. ml (accessed September 25, 2014).

UN. 2004. “Treaty Series: Volume 2173.” New York: United Nations. https://treaties.un.org/ doc/publication/UNTS/Volume\%202173/v2173.pdf (accessed September 25, 2014).

UNDP (United Nations Development Programme). 1994. New Dimensions of Human Security. New York: UNDP. http://hdr.undp.org/en/reports/global/hdr1994/ (accessed September 25, 2014).

UN General Assembly. 2005. Summit Outcome Document. New York: United Nations. http:// daccess-dds-ny.un.org/doc/UNDOC/GEN/N05/487/60/PDF/N0548760. pdf?OpenElement (accessed September 25, 2014).

UN General Assembly. 2012. "Follow up to Paragraph 143 on Human Security of the 2005 World Summit Outcome." New York: United Nations. https://docs.unocha.org/ sites/dms/HSU/Publications\%20and\%20Products/GA\%20Resolutions\%20and\%20 Debate\%20Summaries/GA\%20Resolutions.pdf (accessed October 29, 2014).

UNOCHA (United Nations Office for the Coordination of Humanitarian Affairs). 2012. Guidelines for the United Nations Trust Fund for Human Security. New York: United Nations. http://docs.unocha.org/sites/dms/HSU/Final\%20revised\%20guidelines\%20 2012\%20\%20-2010\%20May\%202013vs2.pdf (accessed September 25, 2014).

UNOCHA. 2013. Human Security Approach. New York: United Nations. http://www. unocha.org/humansecurity/human-security-unit/human-security-approach (accessed September 25, 2014).

UN Security Council. 1999. "Resolution 1265 (1999).” New York: United Nations. http://www.un.org/ga/search/view_doc.asp?symbol=S/RES/1265(1999) (accessed September 25, 2014).

UN Security Council. 2000. “Resolution 1296 (2000).” New York: United Nations. http://daccess-dds-ny.un.org/doc/UNDOC/GEN/N00/399/03/PDF/N0039903. pdf?OpenElement (accessed September 25, 2014).

UNTFHS (United Nations Trust Fund for Human Security). 2013a. "Human Security at the UN." New York: UNOCHA. http:/ /unocha.org/humansecurity/about-humansecurity/human-security-un (accessed September 25, 2014).

UNTFHS. 2013b. "UNTFHS Activities Around the World." New York: UNOCHA. http:// www.unocha.org/humansecurity/trust-fund/un-trust-fund-human-security (accessed September 25, 2014).

Weiss, Thomas, Tatiana Carayannis, and Richard Jolly. 2009. “The 'Third' UN.” Global Governance 15: 123-142.

Zaum, Dominik, Jose Antonio Ocampo, and Rosalind Eyben. 2013. "Book Review: The United Nations Intellectual History Project.” Oxford Development Studies 41 (1): 122137.

\footnotetext{
Neil MacFarlane is Lester B. Pearson Professor of International Relations and Fellow of St. Anne's College. He has written extensively on humanitarian action and human security, notably the coauthored monograph The United Nations and Human Security: A Critical History (2006). His current research focuses on international and regional security, with particular emphasis on the former Soviet Union. E-mail: neil.macfarlane@politics.ox.ac.uk
} 